\title{
Incorporating a Smartphone Video in a Theatrical Activity to Promote an Authentic Language Learning Environment in a Lower Secondary School Classroom
}

\author{
https://doi.org/10.3991/ijim.v14i01.11499 \\ Prima Gusti Yanti, Herri Mulyono ( $₫)$ \\ University of Muhammadiyah Prof. Dr. Hamka, Jakarta, Indonesia \\ hmulyono@uhamka.ac.id
}

\begin{abstract}
Theatrical activities have been used to promote an authentic learning environment. However, the incorporation of simple daily technology, like smartphones, to enable students to produce a video of their theatrical activities has not been explored in the Indonesian language learning classroom. This paper documents a video project conducted by lower secondary school students at a private school in Jakarta, Indonesia to examine whether a video project task could help create an authentic learning environment in a language classroom setting. Although the benefits of theatrical activities to promote authenticity in students' learning experiences are evident in the literature, only a few students have access to such benefits. Many students were reluctant to get involved in the theatrical activities prepared by the teachers and only one cohort of students successfully completed the advertisement video assignment. Teachers' instructional issues as well as students' motivation and commitment to work collaboratively were identified as the barriers to produce the video.
\end{abstract}

Keywords-Theatrical activities, role-play, smartphone video, authentic learning, authentic learning environment

\section{Introduction}

Theatrical activities have been integral features and are widely practised in language learning classrooms [1]. Theatrical activities, such as drama, role play, simulation, tales, reading plays and improvisation reflect the communicative approach to language teaching, suggesting that two main components in the approach: studentcentred and meaning-based learning [2]. In other words, according to Dodson [2], the application of theatrical activities in language classroom allows students to engage with genuine and contextual language use. Students who get involved in drama or role play also have the opportunity to explore the socio-pragmatic language use, both verbal and non-verbal [3]. For example, non-verbal language use that students employ during a play helps to establish a positive interaction between the involved parties, enabling them to engage in a "shared social, symbolic, physical, and mental space" [4, p. 192]. Besides, theatrical activities helps develop students' learning motivation, fos- 
ter their creativity, promotes collaborative learning [5] and helps the students to learn the culture of the target language [2], [3], [6].

The benefits of theatrical activities for students' language learning abound in the literature [2]-[7], particularly activities that facilitate an authentic language learning environment [1], [7]. In this paper, the authentic learning environment reflects a learning situation that allows the students to experience contextual learning linking to realworld tasks [8], [9]. Moreover, Herrington and Oliver [10] offer a framework of authentic learning environment with several principles including:

- Students' access to the learning model and resources

- Students' exploration of varied roles and perspectives

- Students' opportunity to work collaboratively with their peers

- Students' opportunity to reflect on their learning experiences

- Students' opportunity to share their ideas, thoughts and experiences

- Sufficient support from teachers and more able persons

- Real-life assessment

Theatrical activities meet the principles in which students can prepare an advertising role play they find daily on TV, YouTube videos, or social media networks. Students are also given an opportunity to create their own roles or select other roles available to them. Role play activity also enables the students to perform collaborative work, where they can interact and share their ideas with their peers. Within a framework of the Systemic Functional Linguistics (SFL) based instructional approach [11][14], teachers support their students by providing them with learning resources and model text for role play, with students receiving guidance from their teacher, then attempt to work independently [15], [16].

Video making activity, or later called video project, is an alternative that may help the teacher to promote an authentic learning environment through the application of theatrical activities in the classroom [1]. Using daily technology, like a smartphone video, offers students an opportunity to create multimedia learning resources, allowing them to foster their imagination, establish meaningful learning, and more importantly, improve their learning engagement [9]. Nikitina [1] examined how a video project could help create and support authenticity of university students' learning experience, finding that the video project facilitated a diversity of learning outcomes, both in linguistic and non-linguistic aspects. Student participants were reported to actively use the target language during the process of script writing, rehearsal, and when they acted out the scenes. The project also helped to develop students' social competence, including tolerance, responsibility as well as perseverance.

In current study, a smartphone video was incorporated in a theatrical activity to promote an authentic language learning environment. Specifically, this study attempted to examine if a video project task could help create an authentic language learning environment in a lower secondary school setting. The study will be significant in providing the researchers, who are teacher educators, with first-hand experience of the creation of authentic learning environment through the incorporation of smartphone video in a theatrical activity, allowing them to identify the values and challenges dur- 
ing its implementation. The findings will also contribute to the current literature on teacher education internship at secondary schools and language teacher education.

\section{$2 \quad$ Method}

\subsection{Research setting and participants}

The current study examined if a video project task could help create an authentic language learning environment in a lower secondary school setting. This study was part of a teacher educator internship at school (TAIS) year 2018 project initiated by the Ministry of Research, Technology and Higher Education of the Republic of Indonesia. In the TAIS project, university lecturers from the Faculty of Teacher Training and Pedagogy were assigned to conduct collaborative teaching with a private lower secondary school teacher in Jakarta, Indonesia. The first author of this paper performed collaborative teaching with a young female language teacher pseudonymised as Mary. Mary was a fresh graduate with two-years-teaching experience at the school and the students were thirty-four eight grade students aged between twelve and fourteen years old. At the time the study was conducted, the students had just begun their first semester for the academic year 2018-2019.

\subsection{Instructional design and procedure}

To achieve the study aim, a lesson study was adopted in which the authors collaborated with the school teacher to design and examine classroom teaching practices [17], [18]. As suggested by Fernandez [18], study cycles were developed comprising several phases such as collaborative teaching planning, classroom observation, reflection and continuing improvement. Within the lesson study design, the first author of the paper was the co-teacher at the school, while the second author acted as a classroom observer, allowing us to access the school curriculum as well as other relevant documents in addition to facilitating insider perspectives [19], [20]. For the TAIS project, ten teaching and learning sessions were covered, but for the purposes of this paper, only three teaching and learning activities where the smartphone was incorporated to help create an authentic language learning environment in the classroom through theatrical activities were reported. The design of the classroom instruction was developed as below:

\section{Lesson planning}

\section{Objective:}

- Students can identify information in advertisement text

- Students can examine language aspects in advertisement text

- Students can express their ideas, thoughts and creativity on advertisement text

\section{Textbook:}

Harsiatim, Trianto \& Kosasih. 2017. Bahasa Indonesia Kelas VIII. Jakarta: Ministry of Education and Culture 
Meeting and Time allocation:

3 meetings ( 2 x 40 min for each meeting)

Procedure:

Teachers' instructional procedure adopted the four-cycle SFL genre based instructional approach [11]-[14], including:

- Construction of knowledge; in this stage, the teacher introduced the students to the advertisement text by presenting them with advertisement images and watched an advertisement video together

- The modelling stage allowed teachers to explain the linguistic features and organisation of the advertisement text to develop students' awareness of the advert structure as well as the social purposes [21]

- Joint text construction involved group work activities, in which students were asked to construct advertisement texts collaboratively. In this stage, students were assisted by their teachers during the text construction activities [15], [16]

- Independent text construction offered students with opportunities to develop advertisement texts. As suggested by Mulyono [11], students were allowed to select their own topic for the text development

\subsection{Data collection and analysis}

Data were collected from students' videos, teachers' observation as well as teacher reflections. The first author and the teacher taught the lessons to the students, observed by colleagues. During the observation, one of the authors also approached the students and interviewed them about the video project. Such an observation helped teachers to better understanding of their teaching practices [22], [23], evaluated them and addressed issues emerged during the practice. In addition, reflections were written straight after each session [22], [24], [25], then discussed in a meeting, thereby allowing them to be used to improve the teaching in the next session. As suggested by Nikitana [1], all the data were analysed qualitatively using Cohen, Manion, Morrison, and Bell's interpretive research framework [26].

\section{Theatrical Activities and Video Project: The Narratives and Discussion}

All students in the classroom were put in groups of six to prepare a role play video related to a product advertisement. A total of six groups were assigned to prepare six role play videos and students were given two-week's preparation. In addition, students were given an opportunity to select the product advertisement that suited their interest.

At the beginning of the video project, the students were informed about the objective and the requirements of the video they were to prepare. They were also provided with information about the four stages of a video project. At the first presentation and modelling stage, students were asked to find a product advertisement model video to examine the video content, interactions of the actors, language use as well as the crea- 
tivity [1], which is an important tool that may help students to deal with changes in their daily lives [27]. In the video project, the creativity was not merely promoted throughout the design and development of the video, but also students' formulation and use of the target language or termed as linguistic creativity. While watching the video, students were allowed to make notes as necessary. The second discussion stage aimed to facilitate group discussion, allowing students to share their thoughts with other group members in a focus group discussion.

The third stage was script development where the students were asked to prepare the dialogue for their role play. This was conducted in school to allow the students to discuss and consult with their teachers as well as friends. When the script was ready, students were encouraged to start their role play activity in a video recording stage, which was conducted after the language learning session, either in the school yard or at home as a homework to help students to take ownership and control of their own learning activities [28]. Students were allowed to use their smartphone for the video recording process.

Several video recording and editing applications were offered to the students in Google Play such as InShot, EnjoyMobi, CyberLink, KineMaster, Funvideoappstudio, video life, videoshop, VidTrim, Movavi, and Camli (see Figure 1 below).

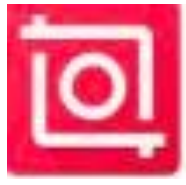

InShot

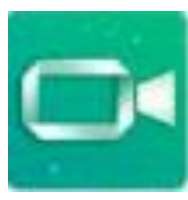

Videolife

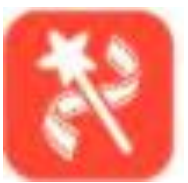

EnjoyMobi

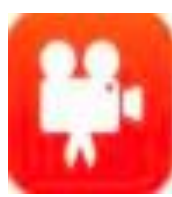

Videoshop

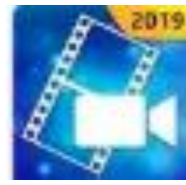

CyberLink

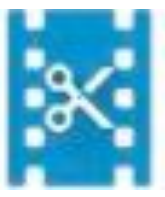

VidTrim

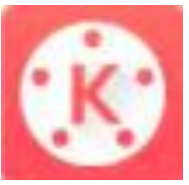

KineMaster

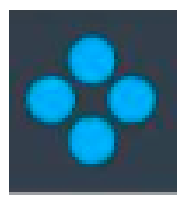

Movavi

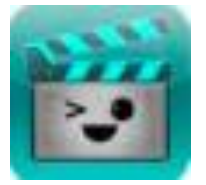

Funvideoapp

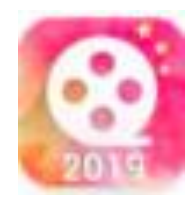

Camli

Fig. 1. Some video recording and editing applications at Google Play

The final stage was video presentation, where students played the video in the classroom and discussed the content, interactions of the actors, language use as well as the creativity, thereby reflecting the students' authentic learning environment [1], [29]. In this regard, students' presentation would enable peer assessment of the learning outcome and accordingly, may enhance their learning performance and competence [29]. 


\subsection{Students' role play video}

Surprisingly, only one group, Group 4, produced their role play video (see Figure 1), improvising a fragrant tea drink advertisement with the video created in the school classroom. Four students (two males and two females) were involved in the video, Aliya, Naomi, Nimar and Nizam, in which they were shown to work hard. One female student, Naomi, approached the two males and asked if they would like a drink, but before they could answer, another girl, Aliya, came with some bottles of fragrant tea drinks and passed them to Naomi, Nimar and Nizam. Only Naomi was shown to drink the tea, while the other two male students were not captured in the video.
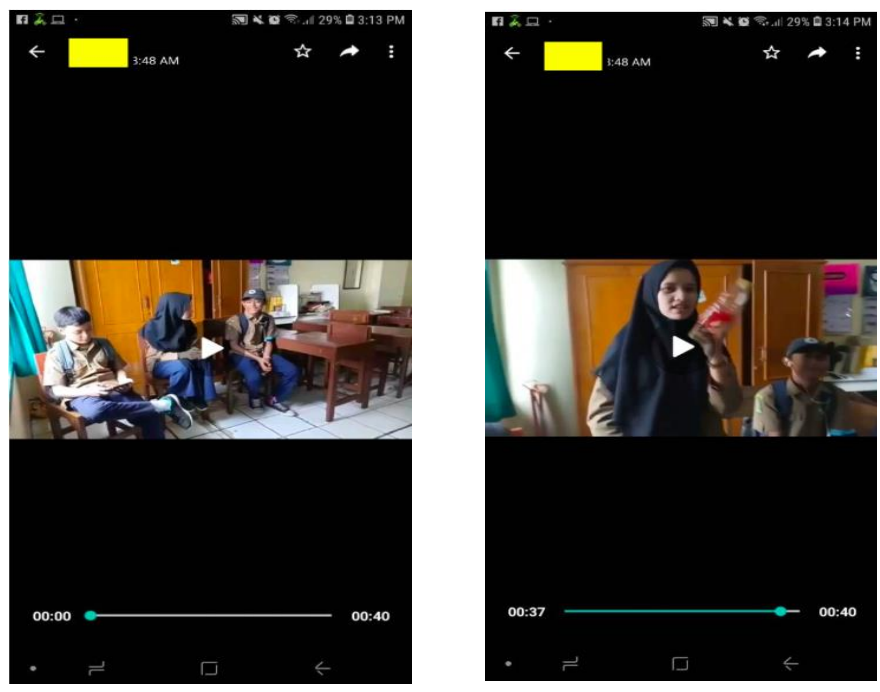

Fig. 2. Role play video prepared by Group 4

The analysis of the students' video showed live interaction among the student actors in an office setting and students' language choices to achieve the social function of advertainment text. For instance, Naomi expressed in the video:

"[After drinking the tea] the fragrant tea drink is really refreshing, especially when the tea water wet your throat."

In other words, the students' video met the genre principle of text as a purposeful and socially constructed act [16], [30]. Although one male student in the video was shown to exhibit little interest during the role play, the students' choice to construct meaning through the role play addressed the SFL's three situation contexts: the field (the site where social action occurs), tenor (the participants and their relation to the text/action) and mode of discourse (the role of language in the events) [14], [31]. In the video for instance, students employed the rhetorical mode of persuasion to attain the advertisement function:

"The tea really tastes good. It is really good. [Naomi smiles]. For you all, do not forget to buy this fragrant tea drink [Naomi points at the bottle]." 
The role play helped the students to recognise and prepare for the complexity of real-life [8], [29]. In the current study, students made use of the above mentioned three situation contexts to attain the primary function of an advertisement text, reflecting students' experience of learning in an authentic environment.

\subsection{Critical challenges in the video project}

The analysis of classroom observation and reflection identified two critical challenges from the video project practice in the classroom, such as students' lack of motivation and work commitment and teachers' instructional issues.

Students' lack of motivation and work commitment. Students were reluctant to engage in the theatrical activity and video project. They perceived that creating a video was easy but working after school hours was challenging in terms of time and work commitment. Almost all students mentioned that they found it difficult to agree a convenient group meeting time. For example, Naufal from group 1 reported "My friends always have excuses to avoid meeting for the video project", similarly, Nala said, "It is quite difficult to work with the video project after school. It was late in the afternoon, and many of my friends already left the school."

While agreeing on time was difficult, two other related issues also emerged during the group work, such as unwillingness to work cooperatively with other peers and disruptive behaviour. Nala affirmed that many of her peers were reluctant to work cooperatively each other. Students' unwillingness to work in a video-taped role play may correspond to students' individual differences. Dodson [2] argues that students' unique characters, abilities to perform, and motivation do not seem to suit the interest of theatrical analysis of all students. Unfortunately, the current study did not anticipate this, ignoring that students failed to sign up to the role play. Consequently, some students may have felt uncomfortable participating in the role play, or if they joined the event, they would have been forced to do so.

Students' disruptive behaviour was also reported by Ramziy, "When waking the video, Fachri always disturbed the process by walking around on the site. The disruptive behaviour discouraged other group members and demotivated them to work with the project." Such issues identified in the current study are also evident in literature, in particular, Mulyono [11] reported similar issues when lower secondary school students developed a descriptive text collaboratively, including discrepancy of students' level of language competence, students' inability to maintain their learning focus and students' interpersonal conflict. Unfortunately, potential sources for students' disruptive behaviour was not apparent in the current study, which made difficult to find solutions to address these issues.

Teachers' classroom instruction issues were the primary concern contributing to students' reluctance to participate in the video project. The analysis of our reflections from the beginning of the lessons revealed that students were not particularly interested in learning.

"In my second visit to the school, I observed that many students had low motivation for learning. I noted some of them rested their head on the desk, while some often went out during the lesson.” (First author' reflection, day 2) 
It was felt that the students viewed the first author as an outsider, consequently making them disrespect the whole teaching and learning process. To remind the readers, the study was part of a TAIS project, in which the first author performed collaborative teaching with the school teacher. In this regard, students might not have perceived the first author as their regular teacher, thereby limiting their relationship and interactions with the first author. Leah and Parsons [32] argue that students' strong relationship with their teachers may improve their engagement in the learning process. Particularly in research, building empathy and rapport is crucial to help students feel convenient and secure, allowing them to disclose any necessary information to the researchers [33].

The quality of our classroom instruction was also of concerns. A study by Kunter, Klusmann, Baumert, Richter, Voss, and Hachfeld [34] suggested that teachers' quality of instruction affects students' learning outcomes. During the video project, students received insufficient information about the assignment and how to complete it. Teachers missed the opportunity to provide students with warm-up activities to help reduce tension and to develop their confidence [5]. Samples of the use of drama as suggested by Turecek [5] were also not provided by the teachers, which may have constrained the development of the students' language skills. More importantly, students did not appreciate the value of the assignment to their daily life, which may have contributed to their lack of engagement in their own learning [32].

Future practice on incorporating smartphone video in theatrical activities to promote authentic language learning environment should address these two issues: quality of classroom instruction and improving students' learning engagement. Enhancing teachers' pedagogical and content knowledge is an alternative solution to address the low quality of classroom instruction [34]. In addition, teachers should be able to improve the quality of students' learning engagement by establishing closer relationships with their students and by providing them with information about the relevancy of their learning with their interests, concerns and their daily life [32], [35].

\section{Conclusion}

The current study attempted to examine if a video project task could help create an authentic language learning environment in a lower secondary school setting. The findings revealed that only a few students benefited from the authentic learning of video-taped theatrical activities, as only one group successfully completed the advertisement video assignment. Nonetheless, the analysis of the students' video showed that their participation in a theatrical activity enabled them to experience authentic learning. Teachers' instructional issues and students' motivation and commitment to work collaboratively were identified as the barriers to work collectively to produce the video. Regarding the TAIS project, the current study findings are significant for the first and second authors, teacher educators at the Faculty of Teacher Training and Pedagogy, in preparing curriculum and activities for prospective language teachers at the university. 


\section{$5 \quad$ Acknowledgement}

This project was funded by the Directorate General of Classroom Instruction and Studentship, Ministry of Research, Technology and Higher Education of Republic of Indonesia, under Contract Number 38/B2.PPK/SPPK/PDS/2018.

No potential conflict of interest was reported by the authors. The advertisement video project and video recorder application used in the current study did not associate with any commercial companies.

\section{$6 \quad$ References}

[1] L. Nikitina, 'Creating an authentic learning environment in language learning classroom', Int. J. Instr., vol. 4, no. 1, pp. 33-46, 2011.

[2] S. L. Dodson, 'FAQs: Learning Languages through Drama.' Texas Pap. Foreign Lang. Educ., vol. 5, no. 1, pp. 129-141, 2000.

[3] C. Ryan-Scheutz and L. M. Colangelo, 'Full-scale theater production and foreign language learning', Foreign Lang. Ann., vol. 37, no. 3, pp. 374-385, 2004. https://doi.org/10.1111/ j.1944-9720.2004.tb02696.x

[4] S. G. McCafferty, 'Gesture and creating zones of proximal development for second language learning', Mod. Lang. J., vol. 86, no. 2, pp. 192-203, 2002. https://doi.org/10.11 11/1540-4781.00144

[5] I. Turecek, 'The significance of theatrical activities for English instruction in primary school', Eur. Educ., vol. 29, no. 4, pp. 53-60, 1997. https://doi.org/10.2753/eue10564934290453

[6] G. Belliveau and W. Kim, 'Drama in L2 learning: A research synthesis', Scenar. Lang. Cult. Lit., vol. 7, no. 2, 2013.

[7] C. Boudreault, 'The benefits of using drama in the ESL/EFL classroom', Internet TESL J., vol. 16 , no. 1 , pp. $1-5,2010$.

[8] R. Shadiev, W. Hwang, Y. Huang, and T. Liu, 'Facilitating application of language skills in authentic environments with a mobile learning system', J. Comput. Assist. Learn., vol. 34, no. 1, pp. 42-52, 2018. https://doi.org/10.1111/jcal.12212

[9] R. Shadiev, W.-Y. Hwang, and Y.-M. Huang, 'Review of research on mobile language learning in authentic environments', Comput. Assist. Lang. Learn., vol. 30, no. 3-4, pp. 284-303, 2017. https://doi.org/10.1080/09588221.2017.1308383

[10] J. A. Herrington and R. Oliver, 'An instructional design framework for authentic learning environments', Educ. Technol. Res. Dev., vol. 48, no. 3, pp. 23-48, 2000.

[11] H. Mulyono, 'Technology enhanced collaborative writing in Indonesian EFL classroom'. Doctoral dissertation. University of York, 2016.

[12] K. Hyland, Second language writing. Cambridge University Press, 2003.

[13] K. Hyland, 'Genre pedagogy: Language, literacy and L2 writing instruction', J. Second Lang. Writ., vol. 16, no. 3, pp. 148-164, 2007. https://doi.org/10.1016/j.jslw.2007.07.005

[14] B. Paltridge, Genre and the language learning classroom. University of Michigan Press, 2001.

[15] H. Ahn, 'Teaching writing skills based on a genre approach to L2 primary school students: An action research', English Lang. Teach., vol. 5, no. 2, pp. 2-16, 2012. https://doi.org/10. 5539/elt.v5n2p2

[16] K. Hyland, Genre and second language writing. University of Michigan Press, 2004. 
[17] C. Fernandez, 'Learning from Japanese approaches to professional development: the case of lesson study', J. Teach. Educ., vol. 53, no. 5, pp. 393-405, 2002.

[18] M. L. Fernandez, 'Investigating how and what prospective teachers learn through microteaching lesson study', Teach. Teach. Educ., vol. 26, no. 2, pp. 351-362, 2010. https://doi. org/10.1016/j.tate.2009.09.012

[19] L. Atkins and S. Wallace, Qualitative research in education. SAGE publications, 2012.

[20] Y. Li and G. Hu, 'Supporting students' assignment writing: what lecturers do in a Master of Education programme', Assess. Eval. High. Educ., vol. 43, no. 1, pp. 1-13, 2016. https ://doi.org/10.1080/02602938.2016.1274017

[21] M. Callaghan and J. Rothery, Teaching factual writing: A genre-based approach. Erskineville: Metropolitan East Disadvantaged Schools Program - New South Wales Department of Education, 1988.

[22] N. Solihati and H. Mulyono, 'A Hybrid classroom instruction in second language teacher education (SLTE): A critical reflection of teacher educators', Int. J. Emerg. Technol. Learn., vol. 12, no. 5, pp. 169-180, 2017. https://doi.org/10.3991/ijet.v12i05.6989

[23] J. C. Richards, 'Beyond training: Approaches to teacher education in language teaching', Lang. Teach., vol. 14, pp. 3-8, 1990.

[24] T. S. C. Farrell, Reflective language teaching: From research to practice. London, New York: Continuum, 2007.

[25] N. Solihati and H. Mulyono, 'Designing and Evaluating the Use of Smartphones to Facilitate Online Testing in Second-Language Teacher Education (SLTE): An AutoEthnographic Study', Int. J. Emerg. Technol. Learn., vol. 13, no. 1, pp. 124-137, 2018. https://doi.org/10.3991/ijet.v13i01.7683

[26] L. Cohen, L. Manion, K. Morrison, and R. Bell, Research methods in education, 8th ed. London: Routledge, 2018.

[27] A. Maley, 'Overview : Creativity - the what, the why and the how', in Creativity in the English language classroom, A. Maley and N. Peachey, Eds. British Council - TeachingEnglish, 2010, pp. 6-13. https://doi.org/10.1057/978-1-137-46729-4_10

[28] A. O. Agbatogun, 'Developing learners' second language communicative competence through active learning: Clickers or communicative approach?', J. Educ. Technol. Soc., vol. 17, no. 2, pp. 257-269, 2014.

[29] A. Herrington and J. A. Herrington, 'What is an authentic learning environment?', in Authentic learning environments in higher education, A. Herrington and J. Herrington, Eds. Information Science Publishing, 2008, pp. 68-77. https://doi.org/10.4018/9781591405948. $\underline{\mathrm{ch} 001}$

[30] A. M. Johns, 'Introduction: Genre in the classroom', in Genre in the classroom: Multiple perspectives, A. M. Johns, Ed. Lawrance Erlbaum Associates, 2002, pp. 3-13.

[31] J. Flowerdew, 'Genre in the classroom: A linguistic approach', in Genre in the classroom: Multiple perspectives, A. M. Johns, Ed. Lawrance Erlbaum Associates, 2002, pp. 91-102.

[32] L. Taylor and J. Parsons, 'Improving student engagement', Curr. issues Educ., vol. 14, no. $1,2011$.

[33] G. Partington, 'Qualitative research interviews: Identifying problems in technique', Issues Educ. Res., vol. 11, no. 2, pp. 32-44, 2011.

[34] M. Kunter, U. Klusmann, J. Baumert, D. Richter, T. Voss, and A. Hachfeld, 'Professional competence of teachers: Effects on instructional quality and student development.', J. Educ. Psychol., vol. 105, no. 3, p. 805, 2013. https://doi.org/10.1037/a0032583

[35] G. Claxton, 'Expanding young people's capacity to learn', Br. J. Educ. Stud., vol. 55, no. 2, pp. 115-134, 2007. 


\section{$7 \quad$ Authors}

Prima Gusti Yanti is an associate professor at the faculty of teacher training and pedagogy, University of Muhammadiyah Prof. DR. HAMKA, Jakarta. She received her Ph.D from the deparment of Language Education at State University of Jakarta. Her research interests include the teaching of Indonesian language and language teacher professional development. (prima_gustiyanti@uhamka.ac.id)

Herri Mulyono is a senior lecturer at at the faculty of teacher training and pedagogy, University of Muhammadiyah Prof. DR. HAMKA, Jakarta. He obtained his $\mathrm{Ph}$.D from University of York, UK with his doctoral research investigating the role of technology in collaborative writing at Indonesian secondary schools. His research interests cover the field of computer assisted language learning (CALL) and foreign language teacher professional development.

Article submitted 2019-08-12. Resubmitted 2019-09-18. Final acceptance 2019-09-21. Final version published as submitted by the authors. 